\title{
Impact of Financial Strategies on Financial Operation of Iran Banks and Develop a Model to Prioritize the Financial Strategy Using Combined Techniques SWOT and AHP
}

\author{
Babak Jamshidi Navid ${ }^{1}$, Mehrdad Ghanbari ${ }^{2}$, Farshid Kheir Allahi ${ }^{3}$, Masoud Barati ${ }^{4}$ \\ Received:20.08.2015 \\ Revised:25.08.2015 \\ Accepted: 30.10.2015
}

\begin{abstract}
Financial strategy is a framework organization which directed the financial decision making resulted from different conditions, dynamic competitors and collection of relative reactions. Financial strategy is one of key factors in organizations and increase shareholder wealth by identifying value drivers. Accordingly, this study aimed to analyze the impact of financial strategy on financial operation of banks and also presented a pattern to develop and prioritize such strategies. To do this purpose, data were collected relative to Iran banks from 2010-2011. Independent variable of this study was determined as financing strategy (combine deposits) and investment strategy (payment facilities) and variables like net interest margin and economic added value were accounted as financial operation criteria (dependent variables). Data were analyzed by Kruskal-Wallis test and using SPSS software. Results of present study indicated that financing strategy influenced significantly on economic added value, but did not influence on net interest margin. In contrast, impact of investment strategy on economic added value was rejected, but on net interest margin was confirmed. In second part, after using Delphi method, viewpoints of scholars in a private bank were collected and relative strategies in four fields of opportunities, threats, strengths and weaknesses were determined and after creating SWOT matrix, they were prioritized using AHP technique and presented a pattern to develop such strategies in an organization.
\end{abstract}

Keyword: financial strategy, net interest margin, economic added value, SWOT analysis, hierarchical analysis, Delphi method. JEL classification: G21, G28

\section{Introduction}

Strategy was defined as a comprehensive image of long-term, objectives and short-term purposes and main policies and programs to achieve these purposes and explain present or future mission and present or future existence of organization. Financial strategy is a collection of dynamic and relative reactions which is implemented regarding mutual positions and activities of other organizations. Financial policy was defined as determination of certain values of financial variables such as determination of certain ratio for dividend distribution among shareholders, financial policy, systematic combination are included which are provided for strategy implementation and accounted as important process in implementation such as cash or production funding. Present theories have examined generally determination of financial policy and assisted mangers in financial decision making, but these theories are one dimensional and stable and final conclusion has been presented by assuming stability of other factors. Author's Address

1,2 Islamic Azad university of Kermanshah branch, Kermanshah, Iran

${ }^{3}$ Razi Kermanshah University, Kermanshah, Iran

${ }^{4}$ Islamic Azad University, Kermanshah, Iran
A financial strategy included analysis of different economic events and other environmental variables, definition and specification of impacts impacts of each variable on firm activity, considering alternative responses, comprehension of relative exchange and evaluation of likely different response of competitors. Based on created images for future, different decision have been made which have been about variables controlled by firm. So, financial managers should make multiple and simultaneous decisions in an environment with permanent changes. In a real world, financial manger should find a way to interact with different financial theories together and this is a role of financial strategy. Basis and mission of financial strategy is respond to unclear and unreasonable positions (Senobar, 1995). Currently, financial strategy has been regarded as one of key factors in organizations and increase shareholders wealth by identifying value drivers (Mehrani, 2001).

Theoretical basis and review of literature

Basis of financial strategy creation

Concept of strategy was stated first by Chinese Philosopher named as "Sun Tzu" which had written in a thesis called "war art" 400 years before Christ. This Philosopher defined this 


\section{Navid et al}

strategy as art and technique of planning, combination of operation to achieve military purposes (Rasoulof, 2003). After World War II, Robert Mc Namara, vice president of Ford Company which was appointed as minister of America defense ministry, stated strategy concept in commerce. In the period after war, by increasing demand and trying to maintain market share, organizations had brought long-term programming based on future prediction. Fluctuation and instability of the economic, political and social environment and lack of proper prediction of environmental variables in an exact shape, made companies to adjust their behaviors regarding new positions. Here, "strategic management" was accounted as instrument that could provide basic decision making in accordance with internal conditions and environmental fluctuation (Mobini Dehkordi and Ashtiayani, 17, 2009).

In following this process, it is necessary for organization to find its real position and all parts of an organization play its appropriate role. As a result, strategic management approach was stated. Today, due to dynamic environment and complex organizations, existence of manager or central core of management have not been qualified lonely to organization development, but it is necessary that each of organization member takes control on his or her moment position according strategic path of organization. Thus, concept of strategic thinking was stated in middle of 1980 which means alignment of efforts in all aspects of the organization.

\section{Status of financial strategies in organization and their parts}

Financial strategy is one of functional strategies of organization. From most investor point of views, financial condition of organization as only certain determining factor of its competitive condition and financial factors resulted in changes in present strategies and implementation programs. To achieve successful implementation of organization strategies, required decision should be made regarding capital funding. At the time of financing decision making, it must be attempted to create best structure for capital condition and Dividend decisions caused that organization makes to provide required capital from external sources. What it plays a key role in capital budgeting decisions, is capital cost of company, because capital cost was used as discount of cash flow as a result of investment projects. Thus, rejection or acceptance of suggested investment projects are related to the most appropriate discount rate or same capital cost. However, company capital cost is followed by capital structure, its financial structure or financial leverage. So, it is expected that change in financing sources combination of capital structure (on capital cost and consequently in company value) are followed by rejection or acceptance of investment projects including effective positive and negative net current value. So, investment decisions, financing, dividend capital in circulation have close relationship together (Aarabi and Abedi, 2010).

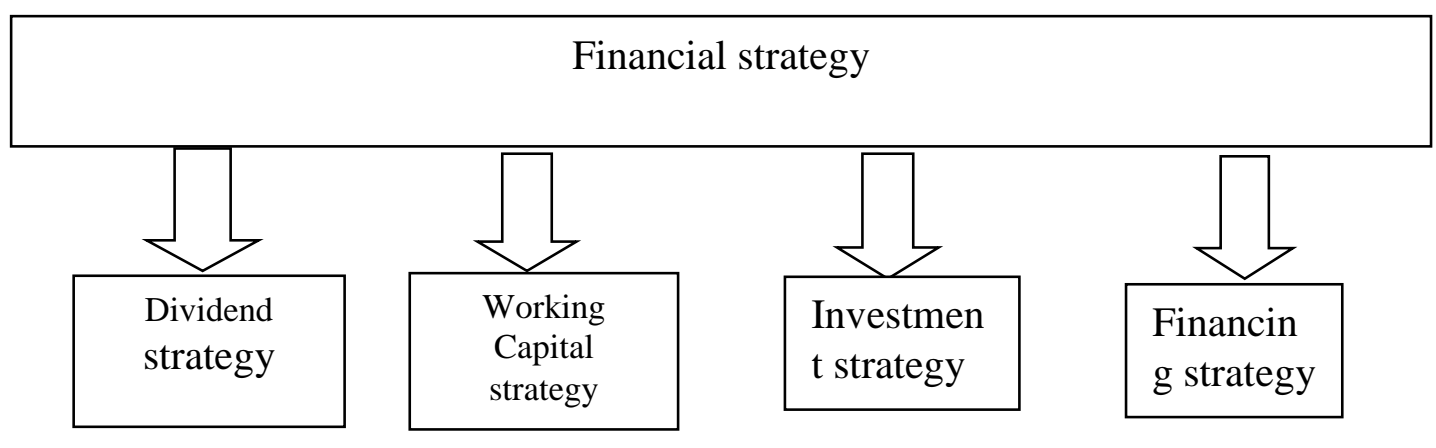

Researchers: source-financial strategy component

From most scholars point of views, financing strategy included investment, financing and dividend that some of them believed that capital in circulation should be added to them.

\section{Importance of strategy in banks and financial institutions}

In a financial system, banks are mediator between depositors and borrowers. In addition, they are responsible for economy, functioning of 
payment and funds settlement and on the other hand, facilitates the implementation of central bank financial policies. Above roles indicated the importance of banks in economy of each country. Creating efficiency in financial sector of economy influences directly on economic growth and development. In addition to relations among financial institutions which should be stable and effective, internal structure of these institutions should be designed so that increase their efficiency (Millani, 2005). Financial institutions like other organizations and due to features such as future decisions and risk combined with its activity kind should take advantage of strategic management process to survive and grow so effectively that generate value maximum
(Rahnamaye Roudpoushti and Eftekhari, 2010). Concerning financial strategies and main tasks of financial management in bank, different viewpoints are presented in financial literature. Important financial decisions in bank can be divided to 4 subcategory (Jahankhani, 1985).

1. Relative decision to differences between rate of return investments and the interest rate paid on deposits.

2. Relative decision to control of operational costs

3. Relative decisions to bank liquidity

4. Relative decisions to bank financial structure.

\section{Review of literature}

Table 1: summary of conducted studies regarding financial strategies in Iran and other countries

\begin{tabular}{|c|c|c|c|}
\hline row & $\begin{array}{l}\text { Name of } \\
\text { researcher and } \\
\text { study date }\end{array}$ & subject & result \\
\hline 1 & $\begin{array}{l}\text { Hasan Pour } \\
(2009)\end{array}$ & $\begin{array}{c}\text { Analysis of effect of capital } \\
\text { strategies in circulation on stock } \\
\text { returns }\end{array}$ & $\begin{array}{l}\text { There are significant relationship between returns } \\
\text { average and different strategies and bold strategy } \\
\text { has the most returns in all industries. }\end{array}$ \\
\hline 2 & $\begin{array}{c}\text { Arabi and } \\
\text { Abedi (2011) }\end{array}$ & $\begin{array}{l}\text { Relationship between financing } \\
\text { strategies, capital in circulation } \\
\text { and dividend with } \\
\text { organizational operation (case } \\
\text { study: Eksir company) }\end{array}$ & $\begin{array}{c}\text { Company operations that have more arrangement } \\
\text { between business strategy and financial strategy } \\
\text { are more than companies that have lower } \\
\text { arrangement. }\end{array}$ \\
\hline 3 & $\begin{array}{c}\text { Arabi and } \\
\text { Abedi (2010) }\end{array}$ & $\begin{array}{l}\text { Arrangement relationship of } \\
\text { business strategy with } \\
\text { organization operation }\end{array}$ & $\begin{array}{c}\text { Company operations that have more arrangement } \\
\text { between business strategy and financial strategy } \\
\text { are more than companies that have lower } \\
\text { arrangement. }\end{array}$ \\
\hline 4 & $\begin{array}{l}\text { Arabi and } \\
\text { Razmjouei } \\
\text { (2011) }\end{array}$ & $\begin{array}{l}\text { Relationship between financial } \\
\text { strategy and company operation }\end{array}$ & $\begin{array}{l}\text { Arrangement between subcategory of financial } \\
\text { strategies with financial strategy improve } \\
\text { company operation, }\end{array}$ \\
\hline 5 & $\begin{array}{l}\text { Ahmadian } \\
(2015)\end{array}$ & $\begin{array}{l}\text { Analysis of Asset-liability } \\
\text { management of Iran banks }\end{array}$ & $\begin{array}{l}\text { Reduction of sources and deposit increase of } \\
\text { investment were dominant strategy of banks in } \\
\text { study period. This strategy reduced liquidity risk } \\
\text { and also increased interest paid to depositors. }\end{array}$ \\
\hline 6 & $\begin{array}{l}\text { Arab Mazar } \\
\text { Yazdi et al } \\
(2013)\end{array}$ & $\begin{array}{l}\text { Relationship between } \\
\text { combination of asset-liability } \\
\text { and liquidity risk in Iran. }\end{array}$ & Relationship between two collection of variables \\
\hline 7 & $\begin{array}{l}\text { Pavlichik } \\
\text { (2009) }\end{array}$ & $\begin{array}{l}\text { Methodology for implementing } \\
\text { financial strategic model in } \\
\text { small and medium markets }\end{array}$ & Presentation of model to specify financial strategy \\
\hline 8 & $\begin{array}{l}\text { Demirgok and } \\
\text { Homyzinga } \\
(1999)\end{array}$ & $\begin{array}{l}\text { Banks activity and financing } \\
\text { strategy: impact on risk and } \\
\text { returns }\end{array}$ & $\begin{array}{c}\text { Powerful relationship between financial strategies } \\
\text { of bank and non-interest earning and powerful } \\
\text { relationship between non- deposits financing and } \\
\text { risk changeability. }\end{array}$ \\
\hline
\end{tabular}




\section{Hypotheses of the study}

Financing strategy of banks influenced significantly on financial operation.

Financing strategy of banks significantly on net interest margin.

Financing strategy of banks influenced significantly on economic value added.

Investment strategy of banks influenced significantly on financial operation.

Investment strategy of banks influenced significantly on net interest margin.

Investment strategy of banks influenced significantly on economic value added.

\section{Questions of the study}

1. How can develop financial strategies based on scientific model?

2. Which financial strategies have priority?

\section{Methodology}

This study is applied one. This study regarded as longitudinal study with retrospective kind, because past data were analyzed to identify probable relations and causes. This study is nonexperimental descriptive-analytic study with casual-comparative kind. In pattern development section, the methodology is survey method and uses Delphi technique. In practice, this study examined first the impact of subcategories of financial operations of banks in Iran and then presented a pattern to develop and prioritize financial strategies of banks using case study.

Population, sampling method and sample size Population of this study included all country banks. This study lacked sampling, but to arrange among studied data, piloting data were conducted:

At end of 31, 1393, bank had activity in country. Regarding time domain of study which included years 1389-1393, 6 banks which were launched during study period, were removed from population of this study. Data of a bank due to substance difference of its activity with other banks (activity on Interest Free Loan), were removed from population of this study. As a result, number of remained banks reached to 24 banks. In response to questions 3 and 4 , population and sample of study is private bank due to using case study.

\section{Methods and instruments of data collection}

In this study, to present theoretical basis and review of literature, library method was used in the form of books, technical articles, dissertations and theses, digital library and searching internet database analysis. In hypotheses testing, to collect study data, document method (total available observations) and database of banking excellence institution and available database in central bank of Islamic republic of Iran were applied. On the other hand, in response to questions 1 and 2, study instruments included interview and weight form which determined by interviewing scholars point of view regarding strategy dimensions and then, by holding brainstorming sessions, strengths and weaknesses and threats and also organization opportunities were identified.

\section{Specification of how to analyze and measure}

\section{variables}

\section{Dependent variable}

Net margin interest:

It is a criteria of net returns of bank profitable assets which includes stock exchange of investment, loads and leasing facilities (Dermine and Bissada, 2002).

$$
\mathrm{NIM}=\frac{\text { net interest revenue }}{\text { earnings assets }}
$$

Net interest revenue $=$ interest earning-interest cost

Earning assets: investment stock exchange, loans and leasing facilities

\section{B: Economic value added:}

From economics point of view, when a company earns economic interest that its accounting interest is more than its investment opportunity cost. Economic value added accounts as basic index to measure company operation and determine its value. Investors and scholars determined company value based on economic value added (Jahankhani and Sajadi, 1995).

To compute economic value added in bank, following equation is used (Thampy \& Baheti, 2000):

EVA $=$ Adjusted Net Profit - (Equity $*$

Cost )Which its components included:

Adjusted net profit to store devaluation demands, unexpected events, accounting Securities.

This computation method, however, instead of calculating the weighted average cost of capital, equity is used which is more proper and simpler for banks. Main reason also referred to fact that in banks, liability management created main part of business and deposits growth has happened generally in lower rate than shareholder opportunity cost. In fact, the bank's balance sheet liabilities was a part of commercial operations of banks and was not accounted liability.

\section{Independent variable \\ Determining variable of financing strategy}

Attraction of financial sources is highly necessary in bank management, because, each 
bank should have required financial sources to implement operation. Banks applied several instruments to attract financial sources which included deposit attraction, taking loan from central bank securities distribution. Main part of bank liabilities related to attracted deposit kinds from depositors (Fallah Shams et al, 2014) . To determine financial strategy kind, first, sensitive liability ratio to total liabilities and equity was computed. Liabilities sensitive to interest rate are long-term and short-term investment deposits which changed its size by interest rate change. Afterward, by computing mean of mentioned variable and determining aggressive strategies (25\% higher than mean), conservative strategy (higher or lower than mean, with distance lower than 25\% SD) and defensive strategy ( with 25\% distance lower than mean), descriptive variables were created (Hasan Pour, 1388 and Ahmadian, 2015).

Determining variables of investment strategy:

Loan is most important operation of commercial banks, development of appropriate policy of loan is highly important to achieve more earning and reduce more risk (Fallah Shams et al, 2014). Thus, to determine investment strategy kind, first, facilities ratio to total assets was computed. Then, by computing mean of mentioned variable and determining aggressive strategies (25\% higher than mean), conservative strategy (higher or lower than mean, with distance lower than $25 \%$ SD) and defensive strategy (with $25 \%$ distance lower than mean), descriptive variables were created.

Normality tests of variables:

Normality test of variables by diagrams

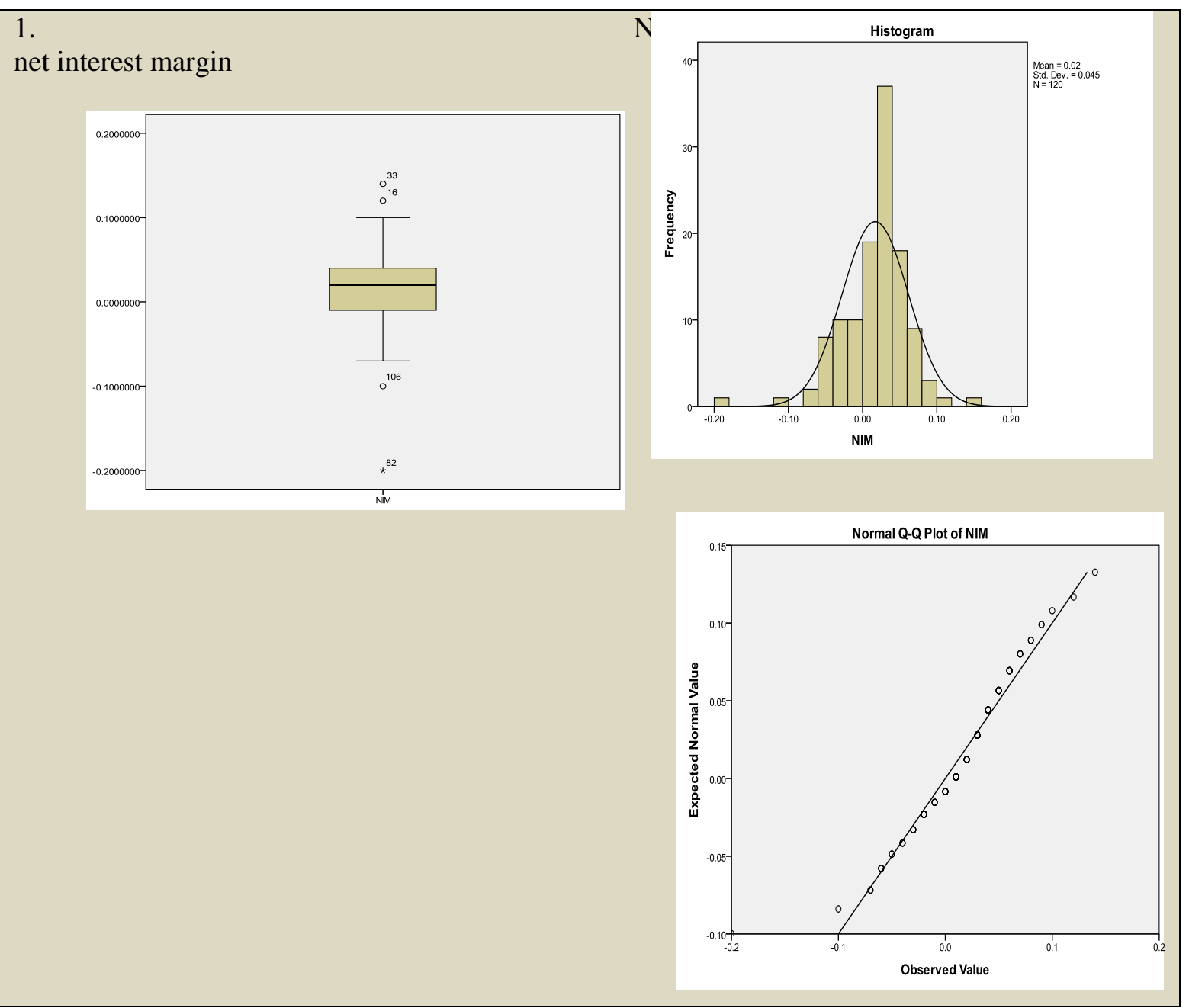

Figure 1: histogram diagrams, plot box and Q-Q relative plot to net interest margin variable

Economic value added: 

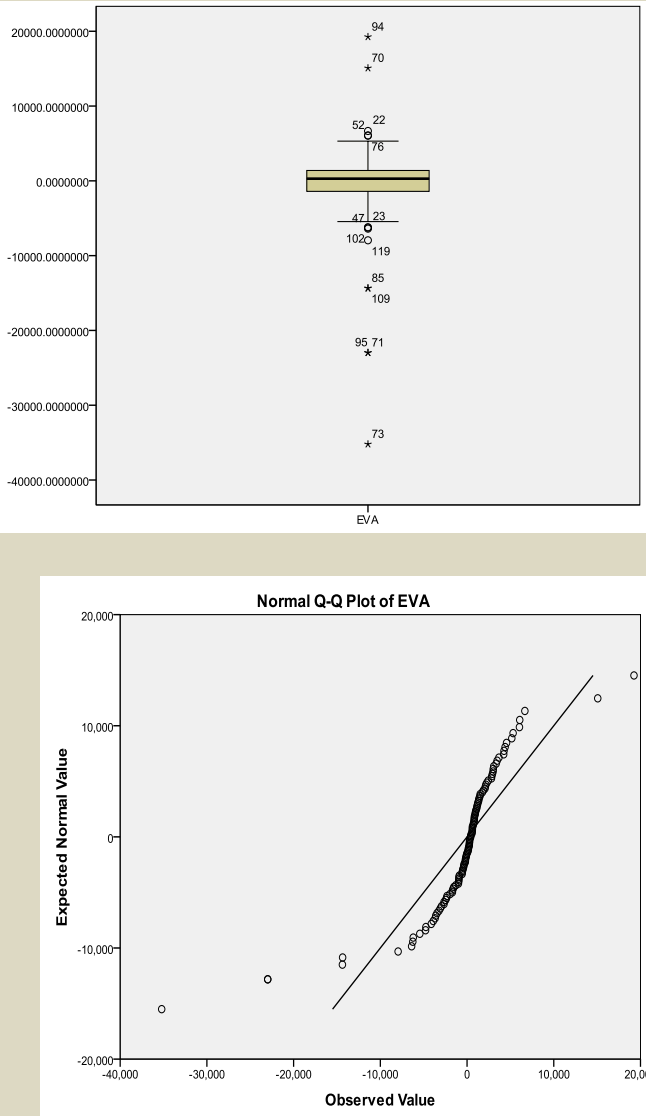

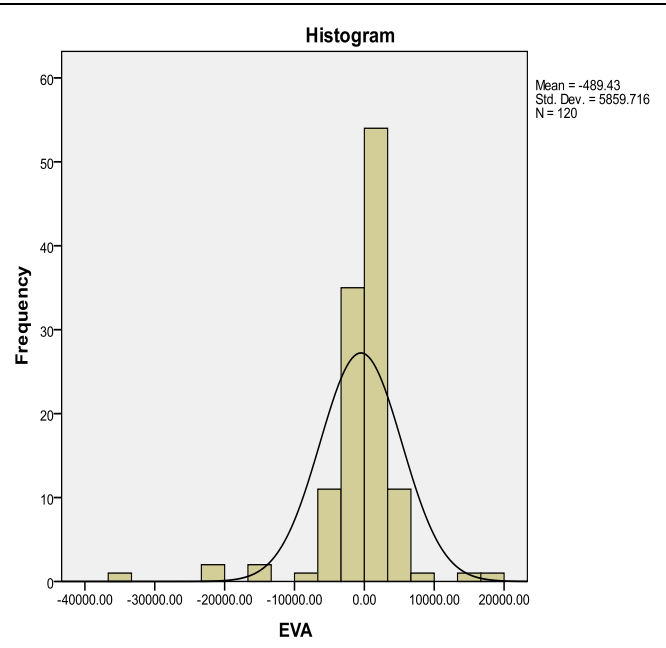

\section{Figure 2: Histogram diagrams, plot box and Q-Q relative plot to economic value added}

\section{Kolmogorov-Smirnov test}

In this part, Kolmogorov-Smirnov test was used to determine data normality. Assumptions of this test included:

H0: mentioned variable included normal distribution.

H1: mentioned variable included abnormal distribution.

To test hypothesis, SPSS software was used. In following table, test results are summarized:

Table 2: Kolmogorov-Smirnov test for net interest margin variable

\begin{tabular}{|c|c|c|c|}
\hline Specification & Frequency & $\begin{array}{c}\text { Kolmogorov- } \\
\text { Smirnov value }\end{array}$ & $\begin{array}{c}\text { Significant } \\
\text { level }\end{array}$ \\
\hline NIM & 120 & $2 / 271$ & 0.78 \\
\hline
\end{tabular}

Table 3: Kolmogorov-Smirnov test for economic value added

\begin{tabular}{|c|c|c|c|}
\hline Specificat & Frequency & Kolmogorov- & Significant \\
\hline EVA & 120 & $5 / 249$ & 0.0 \\
\hline
\end{tabular}

Concerning obtained results of test that test statistic frequency was for variable

EVA more than 0.05 , thus, zero hypothesis was rejected and non-normality of mentioned variable was confirmed 0 in contrast to normality of net interest margin was confirmed. Above presented diagrams were approved this point.

-non-parametric test methods

Due to abnormality of data, this section of study applied non-parametric statistics. Non-parametric methods (free population-distribution) are known, because application of them is not dependent on specific hypothesis about population distribution. One of non-parametric tests which are in accordance with hypotheses of study, is Kruskal-Wallis $\mathrm{H}$ test. When finding differences among three independent group concerning a ranking variable is regarded, this test which is known as $\mathrm{H}$ test, is applied to test equality of means of different societies. Mentioned test based on sum of observation ranks and similar to AOVA analysis, with this difference that it does not require normality of 
data. Statistics of this test is shown with $\mathrm{H}$ and computed as follows:

$H_{0:} \mu_{i j}=\mu_{i m i}=\mu_{i m o}=\mu_{i n}=\frac{12}{N(N+1)} \sum_{i=1}^{k} \frac{R_{i}^{r}}{n_{i}}-3(N+1)$

In above equation, $\mathrm{K}$ population frequency and $\mathrm{N}$ number of member of sum of all societies. Then, above statistic is tested by Chi-square distribution with free degree $\mathrm{K}-1$; if statistic of test is larger than chi-square test, zero hypothesis is not rejected (Saghafi and Jamalian Pour, 2011). In contrast to opposite hypothesis, zero hypothesis of this test emphasizes on lack of difference among groups.

$H_{1:} \mu_{i \#} \mu_{i}$

\section{Testing hypotheses}

1. Financing strategy of banks influenced significantly on financial operation.

1.1. Financing strategy of banks influenced significantly on net interest margin.

1.2. Financing strategy of banks influenced significantly on economic value added.

Table 4: summary of descriptive statistics of first and second hypotheses of study

\begin{tabular}{|c|c|c|c|c|c|c|}
\hline & mean & SD & minimum & maximum & Chi-square & sig \\
\hline NIM & 15.4 & 30.9 & -108 & 48 & 4.35 & 0.114 \\
\hline EVA & -9465 & 8746.1 & -36312 & 2622 & 9.727 & 0.008 \\
\hline
\end{tabular}

Concerning the fact that significance level net interest margin variable is larger than 0.05 , zero hypothesis is confirmed and opposite hypothesis is rejected and in other word, selected financial strategy did not affected on net interest margin. But, concerning economic value added, the significance level is lower than 0.05 which means rejection of zero hypothesis and confirm of opposite hypothesis. In fact, financing strategy affected on economic value added.

2. Capital strategy of banks influenced significantly on financial operation.

2.1. Capital strategy of banks influenced significantly on net interest margin.

2.2. Capital strategy of banks influenced significantly on economic value added

Table 5: summary of descriptive statistics of third and fourth hypotheses

\begin{tabular}{|c|c|c|c|c|c|c|}
\hline & mean & SD & minimum & maximum & Chi-square & sig \\
\hline NIM & 15.4 & 30.9 & -108 & 48 & 7.25 & 0.026 \\
\hline EVA & -9465 & 8746.1 & -36312 & 2622 & 2.895 & 0.235 \\
\hline
\end{tabular}

Above tables measured impact of three capital strategies on dependent variables. Concerning the fact that net interest margin variable is lower than 0.05 , zero hypothesis is rejected and opposite hypothesis is confirmed and in other words, selected capital strategy influenced on net interest margin. But, concerning economic value added, significance level is higher than 0.05 which means confirm of zero hypothesis and rejection of opposite hypothesis. In fact, selected capital did not influenced on economic value added.

\section{Development and prioritize of strategies: Creating SWOT matrix}

Table 6: SWOT matrix of main variables

\begin{tabular}{|c|c|c|c|c|c|}
\hline Groups of SWOT & O & T & S & W & Significance level \\
\hline opportunity & 1 & 2 & 1 & 3 & 0.349 \\
\hline thread & 0.5 & 1 & 2 & 3 & 0.299 \\
\hline Strength & 1 & 0.5 & 1 & 4 & 0.264 \\
\hline Weakness & 0.333 & 0.333 & 0.25 & 1 & 0.088 \\
\hline \multicolumn{7}{|r|}{} \\
\hline
\end{tabular}


Table 7: SWOT matrix of relative components of opportunity

\begin{tabular}{|c|c|c|c|c|c|c|c|c|}
\hline Opportunity & OP1 & OP2 & OP3 & OP4 & OP5 & OP6 & OP7 & $\begin{array}{c}\text { Significance } \\
\text { level }\end{array}$ \\
\hline OP1 & $1 / 0$ & $2 / 0$ & $1 / 0$ & $3 / 0$ & $3 / 0$ & $6 / 0$ & $2 / 0$ & $0 / 218$ \\
\hline OP2 & $0 / 50$ & $1 / 0$ & $3 / 0$ & $3 / 0$ & $6 / 0$ & $4 / 0$ & $4 / 0$ & $0 / 134$ \\
\hline OP3 & $1 / 00$ & $0 / 33$ & $1 / 0$ & $1 / 0$ & $2 / 0$ & $2 / 0$ & $3 / 0$ & $0 / 17$ \\
\hline OP4 & $0 / 33$ & $0 / 33$ & $1 / 00$ & $1 / 0$ & $3 / 0$ & $2 / 0$ & $3 / 0$ & $0 / 083$ \\
\hline OP5 & $0 / 33$ & $1 / 00$ & $0 / 50$ & $1 / 00$ & $1 / 0$ & $3 / 0$ & $2 / 0$ & $0 / 13$ \\
\hline OP6 & $0 / 17$ & $0 / 25$ & $0 / 50$ & $0 / 50$ & $0 / 33$ & $1 / 0$ & $1 / 0$ & $0 / 172$ \\
\hline OP7 & $0 / 50$ & $0 / 25$ & $0 / 33$ & $0 / 33$ & $0 / 50$ & $1 / 00$ & $1 / 0$ & $0 / 092$ \\
\hline compatibility rate $: 0.07$
\end{tabular}

Table 8: SWOT matrix of relative components of threads

\begin{tabular}{|c|c|c|c|c|c|c|}
\hline Threads & $\mathrm{T} 1$ & $\mathrm{~T} 2$ & $\mathrm{~T} 3$ & $\mathrm{~T} 4$ & $\mathrm{~T} 5$ & Significance level \\
\hline $\mathrm{T} 1$ & $1 / 00$ & $3 / 00$ & $1 / 00$ & $1 / 00$ & $7 / 00$ & $0 / 209$ \\
\hline $\mathrm{T} 2$ & $0 / 33$ & $1 / 00$ & $2 / 00$ & $1 / 00$ & $5 / 00$ & $0 / 216$ \\
\hline $\mathrm{T} 3$ & $1 / 00$ & $0 / 50$ & $1 / 00$ & $1 / 00$ & $9 / 00$ & $0 / 127$ \\
\hline $\mathrm{T} 4$ & $1 / 00$ & $1 / 00$ & $1 / 00$ & $1 / 00$ & $9 / 00$ & $0 / 204$ \\
\hline $\mathrm{T} 5$ & $0 / 14$ & $0 / 20$ & $0 / 11$ & $0 / 11$ & $1 / 00$ & $0 / 067$ \\
\hline compatibility rate : & \multicolumn{7}{|l}{} \\
\hline
\end{tabular}

Table 9: SWOT matrix of relative components of strength

\begin{tabular}{|c|c|c|c|c|c|c|}
\hline Strength & $\mathrm{s} 1$ & $\mathrm{~s} 2$ & $\mathrm{~s} 3$ & $\mathrm{~s} 4$ & $\mathrm{~s} 5$ & $\begin{array}{c}\text { Significance } \\
\text { level }\end{array}$ \\
\hline $\mathrm{S} 1$ & 1 & 1 & 2 & 1 & 8 & $0 / 28$ \\
\hline $\mathrm{S} 2$ & $1 / 0$ & 1 & 9 & 3 & 6 & $0 / 426$ \\
\hline $\mathrm{S} 3$ & $0 / 5$ & $0 / 11$ & 1 & 1 & 1 & $0 / 089$ \\
\hline $\mathrm{S} 4$ & $1 / 0$ & $0 / 3$ & $1 / 0$ & 1 & 2 & $0 / 144$ \\
\hline S5 & $0 / 13$ & $0 / 17$ & $1 / 0$ & $0 / 5$ & 1 & $0 / 061$ \\
\hline compatibility rate $: 0.09$
\end{tabular}

Table 10: SWOT matrix of relative components of weakness

\begin{tabular}{|l|c|c|c|c|c|c|c|c|r|}
\hline Weaknesses & $\mathrm{w} 1$ & $\mathrm{w} 2$ & $\mathrm{w} 3$ & $\mathrm{w} 4$ & $\mathrm{w} 5$ & $\mathrm{w} 6$ & $\mathrm{w} 7$ & $\mathrm{w} 8$ & $\begin{array}{c}\text { Significance } \\
\text { level }\end{array}$ \\
\hline $\mathrm{w} 1$ & 1 & 5 & 1 & 2 & 3 & 1 & 1 & 1 & $0 / 089$ \\
\hline $\mathrm{w} 2$ & $0 / 20$ & 1 & 2 & 1 & 1 & 2 & 2 & 6 & $0 / 227$ \\
\hline $\mathrm{w} 3$ & $1 / 00$ & $0 / 50$ & 1 & 1 & 3 & 1 & 1 & 1 & $0 / 084$ \\
\hline $\mathrm{w} 4$ & $0 / 50$ & $1 / 00$ & $1 / 00$ & 1 & 1 & 1 & 1 & 1 & $0 / 109$ \\
\hline $\mathrm{w} 5$ & $0 / 33$ & $1 / 00$ & $0 / 33$ & $1 / 00$ & 1 & 1 & 1 & 9 & $0 / 218$ \\
\hline $\mathrm{w} 6$ & $1 / 00$ & $0 / 50$ & $1 / 00$ & $1 / 00$ & $1 / 00$ & 1 & 1 & 1 & $0 / 101$ \\
\hline $\mathrm{w} 7$ & $1 / 00$ & $0 / 50$ & $1 / 00$ & $1 / 00$ & $1 / 00$ & $1 / 00$ & 1 & 1 & $0 / 101$ \\
\hline $\mathrm{w} 8$ & $1 / 00$ & $0 / 17$ & $1 / 00$ & $1 / 00$ & $0 / 11$ & $1 / 00$ & $1 / 00$ & 1 & $0 / 07$ \\
\hline \multicolumn{7}{l}{ compatibility rate $: 0.08$} \\
\hline
\end{tabular}


Impact of Financial Strategies

Table 11: Matrix of priority determination

\begin{tabular}{|c|c|c|c|c|}
\hline $\begin{array}{l}\text { Groups of } \\
\text { SWOT }\end{array}$ & $\begin{array}{c}\text { Priority } \\
\text { of } \\
\text { group }\end{array}$ & SWOT factors & $\begin{array}{l}\text { priority of } \\
\text { the group }\end{array}$ & $\begin{array}{c}\text { Total } \\
\text { priority of } \\
\text { factors }\end{array}$ \\
\hline \multirow{7}{*}{ Opportunity } & \multirow{7}{*}{$0 / 212$} & $\begin{array}{l}\text { 1O: weakness of stock exchange in financing of economic } \\
\text { markets and surplus of demand in facility sector }\end{array}$ & $0 / 218$ & 0/046216 \\
\hline & & 2O: possibility of using external financing in future months & $0 / 134$ & 0/028408 \\
\hline & & 3O: return of money transformation activity to bank network & $0 / 17$ & 0/03604 \\
\hline & & $\begin{array}{l}\text { 4O: increasing wage remuneration due to opening documentary } \\
\text { letter of credit }\end{array}$ & 0/083 & 0/017596 \\
\hline & & 5O: reducing legal deposit rate by central bank in future months & $0 / 13$ & 0/02756 \\
\hline & & 6O: capital requirement of central bank to enter new banks & $0 / 172$ & 0/036464 \\
\hline & & $\begin{array}{l}\text { 7O: difficulty of attraction of public confidence to a financial } \\
\text { institution }\end{array}$ & 0/092 & 0/019504 \\
\hline \multirow{5}{*}{ Threads } & \multirow{5}{*}{$0 / 268$} & 1T: lower economic growth rate of country & $0 / 209$ & $0 / 056012$ \\
\hline & & 2T: competition among financial institution and banks & $0 / 216$ & $0 / 057888$ \\
\hline & & 3T: lack of government task role playing to banks & $0 / 127$ & 0/034036 \\
\hline & & $\begin{array}{l}\text { 4T:reducing oil price and negative impact on economic growth } \\
\text { and stagflation occurrence }\end{array}$ & $0 / 204$ & $0 / 054672$ \\
\hline & & 5T: creating alternative products such as metal and gold stock & 0/067 & $0 / 017956$ \\
\hline \multirow{5}{*}{ Strength } & \multirow{5}{*}{$0 / 216$} & 1S: appropriate capital basis & $0 / 252$ & $0 / 054432$ \\
\hline & & 2S:presence in stock exchange & $0 / 284$ & 0/061344 \\
\hline & & 3S: liquidity stability & 0/095 & $0 / 02052$ \\
\hline & & 4S: higher capacity of currency exchange & $0 / 238$ & 0/051408 \\
\hline & & 5S: appropriate infrastructure of electronic banking system & $0 / 131$ & 0/028296 \\
\hline \multirow{8}{*}{ Weaknesses } & \multirow{8}{*}{$0 / 134$} & $1 \mathrm{~W}$ : non-profitability of some activity of bank firm & $0 / 147$ & 0/019698 \\
\hline & & $2 \mathrm{~W}$ : non-economic condition of some activity of bank branches & $0 / 13$ & 0/01742 \\
\hline & & $3 \mathrm{~W}$ : inappropriate capital structure & $0 / 164$ & 0/021976 \\
\hline & & $4 \mathrm{~W}$ : lower effective rate of facility & $0 / 117$ & $0 / 015678$ \\
\hline & & $5 \mathrm{~W}$ : higher cost of money & $0 / 161$ & $0 / 021574$ \\
\hline & & $6 \mathrm{~W}:$ lower efficiency rate & $0 / 065$ & 0/00871 \\
\hline & & 7W: higher Personnel costs & $0 / 117$ & $0 / 015678$ \\
\hline & & $8 \mathrm{~W}$ : high assets without returns & 0/099 & 0/013266 \\
\hline
\end{tabular}

Following above table, the highest priority related to s2, t2, t1, t4 and s1. 


\subsection{Presentation of pattern to develop and prioritize financial strategies}
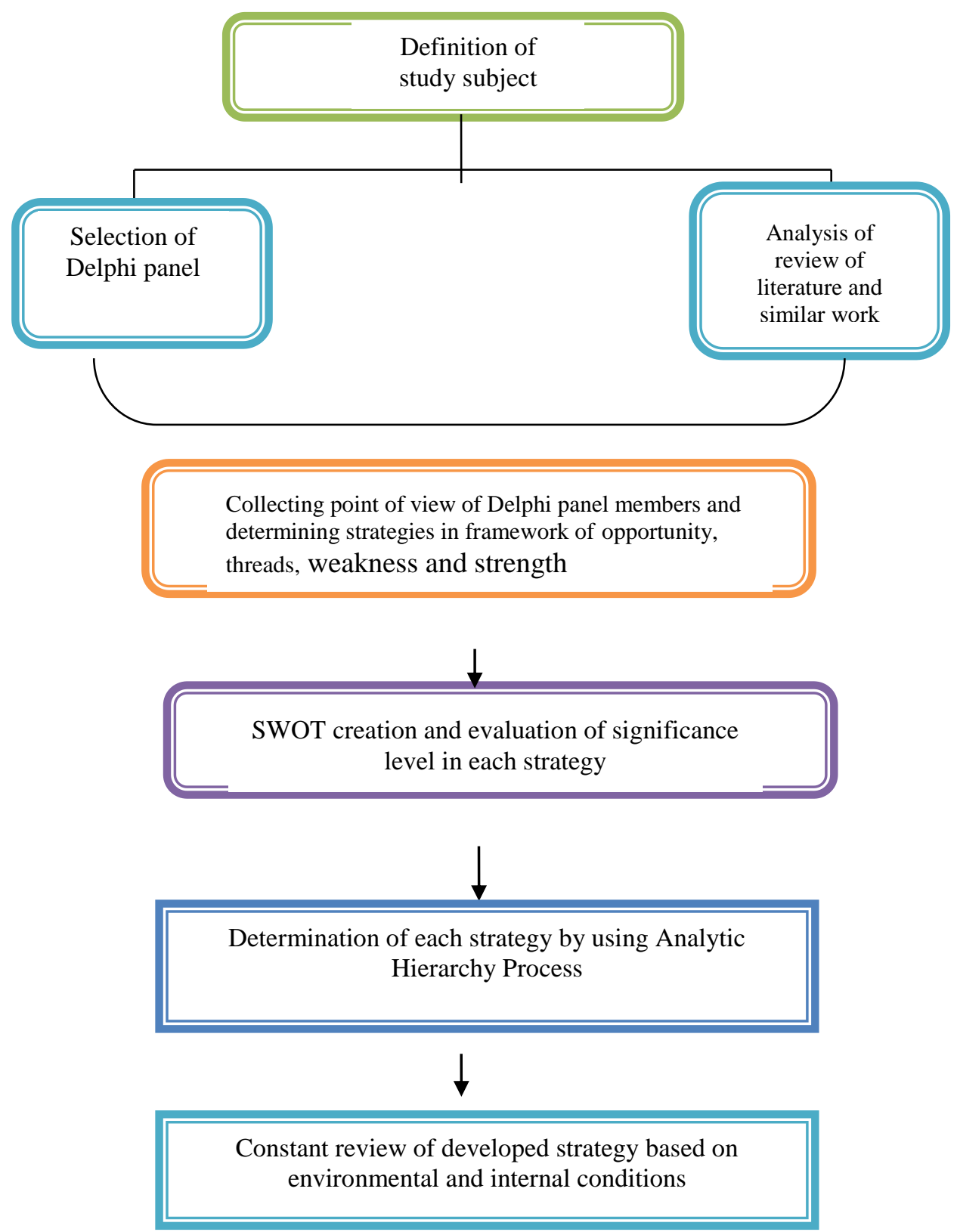

\section{Conclusion}

This study conducted to analyze the impact of financial strategies on financial operation of banks and present a pattern to develop and prioritize these strategies. Based on study findings, impact of financing strategy on economic value added was confirmed, but its impact on net interest margin was not approved. Among effective strategies on economic value added, aggressive had the most impact and defensive strategy had least strategy on economic value added. One the other hand, impact of capital strategy on net interest margin was confirmed and its impact on economic value added was rejected. Among effective strategies on net interest margin, the most impact related to defensive strategy and the least impact related to aggressive strategy. In this section, a pattern was developed to create strategy by using Delphi method and collecting scholar point of views and prioritized by applying Analytic Hierarchy Process and as a result, presented a pattern to develop and prioritize strategies. Findings of this study can be accounted to create strategic thinking and increasing attention to financial strategies in banks. 


\section{References}

Adam, A. 2007. Handbook of Asset and Liability Management, John Wiley \& Sons, New York.

Ahmadian, A. 2015. "Banks asset and liability management strategy ", Journal of Electronic Banking, 13, pp: 48-52.

Amidu, M. 2013." The effects of the structure of banking market and funding strategy on risk and return" International Review of Financial Analysis, No 28, available online at: http://www.ScienceDirect.com.

Angbazo, L. 1997."Commercial Bank Net Interest Margin, Default Risk, Interest Rate Risk and Off Balance Sheet Banking" Journal of Banking and Finance, No 21, 55-87, Available online at: http://www.ScienceDirect.com.

Arab Mazar Yazdi, M., Baghomiyan, R., Kake Khani 2011. "relationship between the composition of assets - debt and liquidity risk of banks in Iran ", available at www.Ensani.ir.

Arabi, M. 2014. "Strategic Planning Handbook", publication of Cultural Research Bureau in Tehran.

Arabi, M., Abedi, R. 2010. "coordination relationship between of business-level strategy and financial strategy and organizational performance ", Journal of Industrial Management, 19.

Arabi, M., Abedi, R. 2011. "coordination relationship between financial strategy, investment, financing, dividends and working capital and organizational performance: Pharmaceutical company of Elixir ", Journal of Management studies in Iran, 4.

Arabi, M., Razmjouie, M. 2013. Financial strategy, Sama Management Research Institute, Tehran.

Arabi, M., Razmjouie, M., Kaviayani, H. 2006. "Review and classification of financial strategies ", paper presented at the First Conference on Strategic Management, Tehran, available at www.civilica.com.

Choudhry, M. 2012, the Principles of Banking, John Wiley \& Sons, New York.

Demirguc-Kunt A, Huizinga H 1999. Determinants of Commercial Bank Interest Margins and Profitability: Some International Evidence. World Bank Economic Review, 13:379-408.

Dermine , J. and Y,F Bissada 2002. Asset \& Liability Management A Guide To Empirical Evidence from Pakistan" Available online at http:// www.textroad.com

Duke, S, B. Ikenna, Nand, S, E Nikamare. 2015." Impact Of Dividend Policy on Share Price Valuation In Nigerian Banks "Archives of Business Research-Vol.3, No.1, available at http://dx.doi.org/10.14738/abr.31.840.

Fallah Shams, M.F 2014. Asset management and banking debt, The Gap Publication, Tehran.

Fard Ara, D. 2008. Strategic management, translated by Ali Parsaeian and Mohammed Arabi, published by the Cultural Research Bureau in Tehran.

Froud, J. Johan, S. and Williams, K. 2006. Financialization and Strategy, Routledge, New York.

Giuliani, F. 2011." Optimal capital structure of a bank: the role of asymmetry of information and Equityzation of Debt" Available online at: http://ssrn.com/abstract=1923824.

Gorner, A., Toker, K., Ulucay, K. 2012. Application of Combined SWOT and AHP: A Case Study for a Manufacturing Firm" Procedia - Social and Behavioral Sciences 58 (2012) 1525 - 1534. Available online at: http://www.sciencedirect.com

Hałaj, Grzegorz 2013." Optimal Asset Structure of a Bank, Bank Reactions to Stressful Market Conditions" available online at http://www.ecb.europa.eu .

Hasan pour, Sh. 2010. "The effect of investment strategies in circulation on stock returns ", Journal of Financial Accounting”, 1.

Hopkins, W., Hopkins, Sh. 1997. "Strategic PlanningFinancial Performance Relationship in Banks: A Causal Examination" Strategic Management Journal, (18)8, pp: 635-652.

Macwiramiti, A, M. 2008." The Implementation Of The New Capital Accord (Basel II): a comparative study of South Africa, Switzerland, Brazil and the United States" Master of MSC, Rhodes University , Grahamstown, Available online http://www.researchgate.net/publication/43309699

Mehrani, K. 2001. "A model for financial strategies, "accountant, 145, pp: 3-6.

Millani, A. 2006. "Strategic planning process aimed at increasing the efficiency of the commercial banks 


\section{Navid et al}

", the tenth Islamic banking seminar, Tehran, available at www.Ensani.ir.

Mobini Dehkordi, A., Sorati Ashtiyani 2010. "Strategic Management for Leaders ", the Institute for International Energy Studies, Tehran.

Moradi, M., Janatifar, H. 2014.’Ranking of Financial Strategies Based on Linear Goal Programming and VIKOR" International Journal of Business Management and Economics, 1(1) 2014, Pages: 16-23 - Available online at http://www.academicjournalscenter.org

Mousavi 2005. “Agricultural Bank's capital structure and financial resources and providing solutions for improving it ", Review of Accounting and Auditing, 39.

Mushtaq, M. 2014." Determinants of Commercial Banks Performance: Value Creation and Risk Control, Prentice Hall, New York

Nabavi, A., Valinezad, S., Ghasemi, J. 2009. A new approach to strategic planning in businesses: small and medium enterprise case study ", paper presented at the Sixth International Conference on Information and Communication Technology Management, Tehran available at www.civilica.com.

Nezamvand Chegini, H., Jalilvand, M.R. 2013. "Strategy formulation approach in specialized banks" Journal of Scanning, 6.

Ogilive, J. 2009. Financial Strategy, Cima Publishing, London.

Pavlice, J. 2009."Corporate Financial Strategy in SME" Paper Proceeding of the World Congress on Engineering, London.

Pavlíček, J. 2009" Corporate Financial Strategy in SMEs" Proceedings of the World Congress on Engineering, 2, London, U.K.
Peterson, P \& Fabozzi, F. 2002. Capital Budgeting: Theory and Practice, John Wiley \& Sons, New York.

Pettit, J. 2007. Strategic Corporate Finance, John Wiley \& Sons, New York.

Raharjo, P, G, 2014." The Determinant of Commercial Banks' Interest Margin in Indonesia: An Analysis of Fixed Effect Panel Regression" Available online At: http://www.econjournals.com.

Rahnamaye, Roudposhti, F., Eftekhari Ali Abadi, A. 2010. "Strategy development with a view to value creation in financial institutions ", Journal of Financial Engineering and Securities Management", 4.

Rasoul of, J. 2004. "management performance Localization of audit system of the banking system, experience the Agricultural Bank ", Proceedings of the Fourteenth Conference on Islamic Banking, Tehran, available at www.ensani.ir.

Salazar, A, L., Soto, R., Rafael, E M. 2012.'The Impact of Financial Decisions and Strategy on Small Business Competitiveness "Global Journal of Business Research, 6(2), Available online at http://www.SSRN.com.

Senobar, N. 1995. "Essential elements of a financial strategy ", Accountant, 111, pp: 60-61.

Thampy, A, Baheti, R. 2000.'Economic Value Added in Banks and Development Financial Institutions", Available online at http://www.SSRN.com.

Vazquez, F and Federico, P. 2012. Bank Funding Structures and Risk: Evidence from the Global Financial Crisis" International Monetary Fund, Available online at http://www.IMF.org. 